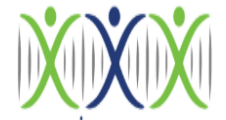

iRASD

\section{Pakistan Journal of Humanities and Social Sciences}

Volume 10, Number 1, 2022, Pages 11-19

Journal Homepage:

https://journals.internationalrasd.org/index.php/pjhss

\title{
Alternative Narrative of Partition: A Lyotardian Analysis of Parmeshar Singh
}

\author{
Ali Raza Fahad ${ }^{1}$, Malik Haq Nawaz Danish², Muhammad Asif ${ }^{3}$ \\ ${ }^{1}$ PhD Scholar in English Literature, Government College University Faisalabad, Pakistan. Email: alrafa80@gmail.com \\ 2 Assistant Professor of English/Deputy Director Colleges, Hafizabad, Pakistan. Email: dani_malik@hotmail.com \\ ${ }^{3}$ Assistant Professor of English, Government College University Faisalabad, Pakistan. Email: masifshafee@yahoo.com
}

\section{ARTICLE INFO}

\begin{tabular}{lr}
\hline Article History: & \\
Received: & November 18, 2021 \\
Revised: & January 05, 2022 \\
Accepted: & January 05, 2022 \\
Available Online: & January 05, 2022 \\
\hline
\end{tabular}

\section{Keywords:}

Alternative Narrative

Meta-Narrative

Postmodernism

Partition Narrative

\section{ABSTRACT}

The study aims at investigating alternative narratives in the partition narrative of the subcontinent concerning the postmodern conditions. The shared knowledge in postmodern traditions invites multiple realities for the epistemology of the perceivers. The Reconstruction of knowledge is marked with putting Meta-narratives into question, especially in the late 1950s in Europe. These constructions of 'realities' in Postmodern traditions import in-depth study of the narratives produced in the specific period of time, unchallenged and accepted until postmodern critique deconstructed the structures of realities. In this response, the partition narrative of Indo-Pak history has been investigated to identify the alternative narratives of the violent event, raging heavy death toll on both sides of the border. Lyotard's alternative narrative technique is framed to identify humane aspects under the bloodshed riddles of the partitions in the partition narratives. The events recorded in the narratives regarding the humane aspects are spotlighted to offer an alternative narrative lying under the cover of the violent partition narrative. Indo-Pak fiction concerning the partition of the sub-continent, giving a ferocious account of the mass immigration across the border and the brutalities on the 'others' on theological details are narrowed down. Amongst these violent accounts of partition, showing a hostile face of the event, humane aspects are ignored to be acknowledged and partition is always propagated as a nightmare with bloodshed, brutality, and savagery. The present study focuses on providing sufficient grounds to proceed by alternating narratives from the nexus of partition towards a humanitarian approach.

(C) 2022 The Authors, Published by iRASD. This is an Open Access Article under the Creative Common Attribution Non-Commercial 4.0

Corresponding Author's Email: alrafa80@gmail.com

\section{Introduction}

Postmodernism as a term is used to allude to a reaction to modernism. Postmodernism is marked with features conflicting to realism and traditionalism. Postmodernists accepts the notion 'irrational is real, real is irrational' and unlike modernism, postmodernism welcomes fragmentation. In postmodernism, there are no premeditated rules, well-celebrated and longstanding principles. Moreover, thoughts, manners and activities for postmodernists exist for a short time. Unlike traditionalism, all these issues are bound to change. Postmodernism asserts that this universe does not have any absolute truth. Postmodernists believe that "we can no longer represent the historical past; but can only 'represent' our ideas and stereotypes about the past" (Jameson, 1991).

The postmodernists are known for presenting the real in the sense of creating a real and ultimately achieving something unpresentable into a nostalgic accepted perception of the real. The construction in this regard is what postmodernist celebrate as meta-narratives that are developed later on into new perceptions of master narrative. In such deconstruction, the major role is played by the scientific discoveries that turn these established facts into simplistic 
and reductionist truths. This 'play' in the meaning is what makes multiple facets of reality possible and explore language games in establishing postmodern conditions, determining the acceptability instead of the 'real', or recurring real.

In this respect, Jean-François Lyotard in his book 'Postmodern Conditions' claims that the grands récits ${ }^{1}$ are no longer credible as they have lost their credibility. Fragmentation and decentralizing of the accepted truth is the main feature of postmodern condition where no meta-language dominates the system of domination. Lyotard accentuates fragmentation and strictly rejects totality, like avant-garde movements which questioned the coherence and autonomy of a literary work. He intellectualizes postmodern as an incredulity towards metanarratives. He furthers his arguments stating that the facts are mere myths or fables to be accepted by the common people and as they are considered as 'truth', the implications of these accepted truths are dangerous. It chronicles the whole cultural imperialism from the rise of Western civilization. It is necessary to identify its special tenor, which keeps it apart from all other practices of imperialism and a demand of legitimation governs it. Legitimation is seen in crisis by Lyotard and he terms it as a symptom of contamination of "meta-knowledge' caused by the poison of belief and ideology (J.-F. Lyotard, 1984).

The challenge that postmodern condition manifests is the idea that the truth is liable to be deconstructed and questioned in sense of claiming totality in the grand narrative. Lyotard's critique is a response to the enlightenment which spawns meta-narratives and enlightenment. The history of progress ensures peace and prosperity, but the last century has seen more bloodshed as compared to the rest of the human history. For Lyotard, meta-narratives first tell a grand tale then claim to legitimize the claim of the story by an invoking the universal reason. Through legitimation myth of progress becomes a meta-narrative.

In the same fashion, the event of partition of British India is termed as a bloody and horrifying event in the history of the subcontinent. The grand narrative regarding partition of British India has been constructed as a brutal sign of great massacre that leaves nothing but bloodshed and butchery, claiming millions of lives on either side of the border and leaving people homeless and helpless. It has always been rendered as a nightmare that never happened in the human history but in the history of British India. Volumes of Partition narratives have been produced from both side of the border which mostly project or strengthen the grand narrative of partition. Still there are some worked produced both by the Pakistani and Indian writers which show the humane side of the partition and reject the grand narrative of partition in specific mood of description and grim details. Under the Lyotardian theory of meta-narrative, Parmeshar Singh by Ahmed Nadeem Qasmi is taken as case study in this present study (Qamsi, 1958). The story Parmeshar Singh is investigated with a perspective of locating humanitarian approach for the 'other' by the 'other' in the land of the 'other'. The research questions are;

- How is partition narrated in Parmeshar Singh?

- How alternative narrative can be located in Parmeshar Singh?

\section{Theoretical Framework}

This qualitative research tends to apply a postmodern approach towards the selected fiction of Ahmad Nadeem Qasmi. Postmodern theory, suggested by one of the major theorists namely Linda Hutcheon and Jean-François Lyotard whose works are thought as landmark in the development of Postmodernism, has been employed to accomplish this research. Within the premises of postmodernism, Hutcheon's theory of 'histographic meta-fiction' and Lyotard's theory of 'meta-narrative' have been deployed to prove the hypothesis regarding partition narratives. The flux of the narrative given by the writer is critiqued by the technique of exploring histographic meta-fiction and alternating aspects of 'constructed real' instead of accepted real.

\section{Postmodernism}

Postmodernism is a term that is complicatedly hard to delineate and delimit. Postmodernism encompasses all the unquestioned aspects of modernism to question their

\footnotetext{
${ }^{1}$ Grand narratives
} 
validity in the postmodern conditions. Postmodernism, as an intellectual phenomenon, challenged modernist beliefs which were inculcated during the Enlightenment. The prospect of human development, marvels of science and inherit potential of human reason to explore the fundamental truth in the social conditions is the core to the rational control (Boyne \& Rattansi, 1990). Postmodernism, as a term, refers to a wide range of academic critics, artists, philosophers and social scientists as Butler (2003) alludes to "a loosely constituted and quarrelsome political party." Melford Spiro, an anthropologist delineates postmodernism arguing that the critique in postmodern fashion is reciprocal to the argument developed between ideological and epistemological stances where both have roots in subjective opinion 'since objectivity is an illusion, science according to the ideological argument, subverts oppressed groups, females, ethnics, third-world peoples (Spiro, 1996).

Postmodernism started as a heterogeneous social phenomenon and further branched out as aesthetics, science philosophy and architecture (Bishop, 1996). Postmodern thinking was noticeably originated in nineteenth century in accordance with Nietzsche's theories in respect of language, society and truth which prompted all the succeeding postmodernists about the fundamentals of knowledge (Kuznar, 2008). Nietzsche claims that truth was merely, a mobile army of metaphors, metonyms, and anthropomorphisms - in short, a sum of human relations, which have been enhanced, transposed, and embellished poetically and rhetorically, and which after long use seem firm, canonical, and obligatory to a people: truths are illusions about which one has forgotten that this is what they are (Nietzsche, 1954).

For Kuznar, postmodernists probe this skepticism regarding truth and the consequent relativism it comes from Nietzsche to Max Weber and Sigmund Freud and ultimately passes to Jacques Derrida, Michel Foucault and the contemporary postmodern theorists. The immediate conception of postmodernism that is often perceived is the ideas like fracturing, deconstruction, fragmentation, plurality and indeterminacy which are the basic elements of postmodernism but one should be aware of the fact that post-modernity is a fractured and fragmentary discourse itself. Many of the literary, artistic and cultural movement can be located in 1950 s to 1960 s which can be labeled as postmodern. The term postmodern and post-modernity became popular in 1970s to 1990s in North American and European societies. It was a fashion during these three decades to describe every new work and innovation as postmodern, especially, when the news media started describing every bit of information under the implication of postmodern spectrum. From Cabbage Patch Kid dolls ${ }^{2}$ to chaos theory ${ }^{3}$, Band $\mathrm{Aid}^{4}$ to war in the Balkans ${ }^{5}$ nearly everything that happened on the cultural arena during that time was celebrated as new evidence of the postmodern. The ideas and concepts deployed by the postmodernists are still prevalent in the contemporary culture and are crucial to modern debates though the postmodern seems less omnipresent.

Before delimitating the intellection of postmodernism, some terminologies need to be addressed. The words 'postmodernism', 'post-modernity', 'postmodern', or 'postmodernist' seem assuming dissimilar meanings in different contexts. The vitally important contexts are: the philosophical, the historical and the literary. The term 'postmodern' in the historical context is the period which succeeds modernity, the same way modernity follows the middle Ages (Best, 1991). Post-modernity was coined by Toynbee, a British historian, in his view post-modernity starts in the last decade of $19^{\text {th }}$ century. The major traits of the years were war, anarchy and transition. The previous modern era as conceived by Toynbee is marked with the social stability, progress and rationalism that is specific for the middle-class bourgeois amidst war and revolution. The postmodern age, by contrast, is a 'Time of Troubles' marked by the collapse of rationalism and the ethos of the Enlightenment (Best, 1991).

\section{Lyotard's Theory of Meta-narratives}

Jean-Francois Lyotard is the theoretical founding father of postmodernism. His most significant contribution to the theory is La Condition Postmodern, a critique that defines the conditions of knowledge in the postindustrial societies.

Lyotard in his critique confronts the Western philosophy and epistemology which use

\footnotetext{
${ }^{2}$ A toy doll

3 Mathematical studies that investigate the condition and behavior

${ }^{4}$ Adhesive bandages used in USA to stop the leak.

5 The Balkan Wars broke out in S. Eastern Europe from1912-14 13
} 
binaries like 'discourse/perception', 'universality/singularity', 'rationality/ irrationality' etc, in a fundamental way. He reasons that first of the above terms has always been privileged in traditional Western thought without ever questioning. Consequently, Lyotard tends to back the under-privileged terms.

Modernism asserts the preferences in unifying the models and theories in terms of binary oppositions. Lyotard argues that the structurality of such unifying theories is inclined to violate the singularity of meanings and particularly of phenomena. 'Reason and power is one and the same thing' (J. Lyotard, 1992). This validates the depiction of meta-narratives as dejecting the effects of the opposite, rationality overpowers unreasoning. (Best, 1991) realizes that the strategy adopted by Lyotard is to criticize the meta-narratives from within, seeking leads from the inner contradictions and fissures.

Lyotard gives importance to deconstructing meta-narratives on three bases. $\mathrm{He}$ challenges the meta-narratives of development, meta-narratives of progress and metanarrative of truth. He suspects the validity of the meta-narratives that leads to the postmodern conditions, where established modes of thoughts are mainly produced by running metanarratives.

Linda Hutcheon accepts the provocation in Lyotard's argument about the pertinence of previously marginalized for postmodern art, decentralizing the subject and discourses and new vision of locating singularity in the knowledge. This comments Lyotard's tendency of being too severe. She asserts that the 'reversal of all values' in Lyotard is universalistic in itself, maintaining the position where proposed particularity is not certain. The critique of metanarratives has been pointed out by the Sorists to be perfectly in order and human conditions in making sense of the world to be indispensable to the interpretations of the meta-narratives.

The postmodern narrative text oscillates between acceptance and refusal. They do not condemn certain discourses. The position can be broken down and these meta-narratives are questioned in postmodernist literature.

This study mainly focuses on the critiques of partition narrative and the massacre in its wake and further investigates the meta-narratives in the process of narrativising the event as the two very narratives are interlinked closely to each other in the literary context of 'postmodernism'.

\section{Textual Analysis}

The historical event of partition of the subcontinent triggers the imagination of the writers of both Pakistan and India to produce volumes of literature. These works portray the events of partition especially the communal, violent, callous and inhuman ones. This treatment of the partition based on the meta-knowledge led to the construction of grand-narrative of hatred and enmity. There was a conscious attempt in Pakistan and India to build a national narrative to propagate and rationalize their respective ideologies. They exploited the masses and inculcated the meta-narrative of hatred and acrimony. Lyotard, the postmodern theorist, investigates into the meta-narratives and found them to be politically motivated constructions. This postmodern theory of rejection of meta-narratives has been utilized to deconstruct metanarratives of the partition through works like Parmeshar Singh.

In the opening scene of the fiction 'Parmeshar Singh', Akhtar, a five years old Muslim boy is separated from his mother and is lost while getting across the border and is surrounded by a Sikh band of rioters. They are about to kill him when Parmeshar saves him from being butchered by his Sikh folks. He beseeches them not to mock at the frightened child. "Don't laugh, yaaro", he said. "After all, the same Vahguruji ${ }^{7}$ made this child as he made you and your children" (Qasmi, 2010). This act of Parmeshar shows sheer humanity and these are the words of compassion. He stands against his own race, overcomes his own feeling of disgust and vengeance and saves a Muslim child from being killed. He requests his companions not to laugh at the misery of a terrified child rather he tries to invoke the feelings of humanity by

\footnotetext{
${ }^{6}$ An addressing term in Punjabi meaning friends or folks

${ }^{7}$ Vahguruji is a term commonly spoken in Sikhism, exclusively refer to God, the supreme Creator.
} 
reminding them of their Vahguruji who, according to them, is the creator of every human being including the Muslim child. Religion was the basic reason of the divide of the subcontinent. In fact, a separate homeland for the Muslims of India was demanded on the basis of two nation theory that designates the Hindus and the Muslims as two different nations. And the slogan of a separate Muslim state was so lauded after the Lahore Resolution 1940. There was a new perception of 'othering' among the masses. They started feeling insecure and this insecurity about the future led to an identity crisis. It was a great threat to be a non-Muslim in Pakistan and to be a, Muslim in India. The violence first broke out due to some motivated fanatics. Hence, there was an atmosphere of communal frenzy that provoked people to butcher every other religionist. This communal violence was the most celebrated theme of the partition literature. They exploited the feelings of the readers by exhibiting too much intense communal violence.

In such an atmosphere, words of a Sikh goon for a Muslim are so strange and kind. He must be very much conscious of his stance that it may provoke his companions against him as well. For they were also the victims of the tumult of the partition and now they wanted to take revenge of the atrocities they had suffered. Parmeshar emerges as a great human being who has fellow feelings for others and he has got the courage to go against his own folks for the sake of humanity and compassion. He assuages his own grief and endeavours to save a human being from the same fate he has suffered. He preaches equality and kindness for all and discourages hatred and fanaticism. Here he is no more a Sikh but only a human being belonging to no caste or creed.

Religion was the basic element of hatred among the people of subcontinent. At the time of partition, the recognition of the person other than one's religion was no less than death warrant for him. When the gang men jeer at Akhtar and ask him about his creator, Akhtar replies them so naively that they burst into laughter.

Tell us who's made you?"- Khuda or Vahguruji?" ...... He spat out a tear which had run into his mouth and said, "I don't know" ... "Amma 8 says she found me lying on the pile of hay inside a little barn.' (Qasmi, 2010).

Akhtar's reply is a sharp criticism on the man-made division on the base of religion. He does not have even the slightest idea of religious malice. Both Parmeshar and Akhtar stand above all religions and this unique bond of humanity binds them together. There is an implicit reason behind Parmeshar's compassion for the Muslim child. Before the partition, the Muslims and the Sikhs had been enjoying a healthy relationship. These feelings can be suppressed but cannot be eliminated. In addition, Akhtar and Kartar have some commonalities. Akhtar was found from a barn and so was Kartar, Akhtar is just a five-year-old kid and Kartar is also of his age. Akhtar is separated from his mother and Parmeshar has also lost his son Kartar. Parmeshar notices that there is a mole on Akhtar's cheek and it reminds him of the mole on the Kartar's cheek. Violence and bloodshed was a recourse for those who suffered while migrating. They wanted to seek revenge on the people who were alleged to be the responsible for their misery. Parmeshar himself suffers a lot as he has lost his own son during the migration, from Lahore to Amritsar. Innocence of Akhtar rekindles Parmeshar's fatherly affection towards Akhtar. He becomes a universal fatherly figure and develops a father-son relationship. On the micro-level he identifies Akhtar with Kartar and in saving Akhtar, he is actually saving his own son, Kartar. There is a fear in his unconscious that his Kartar may not be suffering the same fate and this act of kindness may save him. On the macro-level Akhtar and Parmeshar Singh represent two different communities, the Muslims and the Sikhs. Parmeshar's act of saving Akhtar shows that there were many people who risked their own lives to save people belonging to other communities and religions.

Parmeshar's reaction to Akhtar's words was quite surprising for his companions as he burst into tears. Like his fellows, he had come there to avenge himself on the Muslims for the atrocities they were subjected to. "He started to wail, 'All children are alike, yaaro. Exactly the words of my darling Kartar. Wasn't he too found by his mother lying on a pile of hay inside a barn?" There was cultural harmony in the pre-partition British India. The fact that both Kartar and Akhtar were found on a pile of hay inside a barn indicates that the Sikhs and the Muslims

\footnotetext{
${ }^{8}$ A vocable used for mother in Urdu and Punjabi 
were sharing the same rural culture of Punjab. The recollection of Kartar intensifies with the presence of Akhtar and it leads to an emotional attachment between Akhtar and Parmeshar. The very presence of Akhtar melted his heart as he was not so callous as he was pretending to be but was overcome by the instinct of revenge for the time being.

The $\operatorname{kirpan}^{9}$ was sheathed. His companions negotiate to decide the fate of Akhtar. After the discussion, a Sikh comes forwards and says to Parmeshar: "Here, Parmeshar, take him. Let him grow his kes ${ }^{10}$, make him your Kartar. Here, take him." (Qasmi, 2010). Parmeshar's kind act normalizes others and compels them to shun their grudges and vengeance. They too become humane and spare Akhtar. They themselves offer him to Parmeshar as a son. Bloodshed incited brutality whereas compassion awakened humanity among the people.

When he asks the boy what his name is, he answers "Akhtar." he calls him "Akhtar my son". These words of Parmeshar Singh clearly express endearment and acceptance of Akhtar as a son. He catches a butterfly in order to make Akhtar happy. Actually, he wants Akhtar to come out of the trauma he has just received. Akhtar loves butterflies and it would deviate his attention from the tragic separation from his mother momentarily. He fetches butterfly for Akhtar as he wants to win his heart and bring him close to himself. He has adopted him as a son and it is his duty now to take care of his every bliss. He gifts a butterfly to Akhtar because his real son, Kartar, also liked butterflies. His act of gifting a butterfly to Akhtar demonstrates that he has accepted Akhtar as his real son and he is trying to please him as he used to love Kartar.

When Parmeshar seats Akhtar on his shoulders, he begins to cry. He tries to appease Akhtar by patting him but Akhtar shunts his hand and insists on seeing his mother. His action of bearing Akhtar on his shoulders is tantamount to protecting and sustaining humanity. In the chaotic situation, he chooses humanity when he has to decide between humanity and savagery. In fact, a human being is protecting another human being for the sake of humanity, irrespective of their religious difference. When he embraces Akhtar, he embraces humanity. He has the courage enough to take the responsibility of protecting humanity whereas his band men consider his action an act of madness. This madness distinguishes him as a noble and considerate human being. When Akhtar gets annoyed by Parmeshar's patting, Parmeshar is not irritated, rather he tries to console him.

Parmeshar enters home with Akhtar on his shoulders, he is "uncharacteristically all smiles." (Qasmi, 2010). His hair is untucked and dishelleved. He introduces Akhtar to his wife and daughter. "Don't be afraid, silly woman. He's so much like Kartar." .... "His name is Akhtar" (Qasmi, 2010). The presence of a Muslim in a Sikh household was unimaginable and intolerable. That is why, before disclosing his name, he tries to pacify his wife by narrating similarities between their lost son and Akhtar. His wife's reaction is the reaction of the whole Sikh community in which there is no place for a Muslim. She protests against Akhtar's entry but Parmeshar Singh has undergone a change where he has eroded all his prejudice and malice. The distance that he covered up to his home symbolizes his transformation from a bigoted Sikh to a compassionate human being. His untucked and disheveled hair while he is carrying Akhtar illustrates that he is liberating himself from religious orthodoxy and is growing more and more humane, full of freedom and choice.

His wife threatened to butcher Akhtar and it infuriates Parmeshar. He retorts "maybe I should slash your throat instead." (Qasmi, 2010). Akhtar, Parmeshar Singh and his wife represent three different worldviews: Akhtar represents the innocent victims of the communal violence; Parmeshar's wife is a symbol of rioters and Parmeshar himself represents the sane and humane voice of the society. His act is really courageous as he rebels against his family, his friends and society. First, he saves Akhtar from rioters who were his friends and then he decides to raise Akhtar in spite of his wife's protest. And lastly, he absorbs the societal pressure but does not desert Akhtar. His place in his kins, friends and society, is at stake. He is confronting the whole social structure for the sake of one child-humanity.

\footnotetext{
${ }^{9}$ A kind of dagger that Sikhs keep with them as a religious obligation.

${ }^{10}$ Uncut hair of Sikhs which they keep as a part of religion.
} 
He tries to assure Akhtar that he is his well-wisher. He says," I swear by your God, I am your friend." (Qasmi, 2010). He swears by Akhtar's God to make him realize that there is a close affinity between them and Akhtar can trust him. He tries to befriend him to come closer. His swearing and Akhtar's hesitation manifest the trust deficit due to the fanaticism that both the communities were experiencing after the partition. Both the communities suspected each other and were not ready to trust any more. Parmeshar tries to mitigate the trust deficit between the two communities and wants to re-establish the pre-partition harmony.

An old neighbour consoles Parmeshar that Akhtar will look like Kartar if he grows his kes. Parmeshar gets angry on listening to this idea. He replies, "yaaro, you couldn't be crueller. You want to make Akhtar into Kartara. What if somebody over there made Kartara into Akhtar? Wouldn't you call such a person heartless?" ...."This boy, I'm telling you, will remain Muslim" (Qasmi, 2010). He stands against religious fanaticism and supports Akhtar. He saves him from his possible conversion. He gives a balanced worldview that all human beings are free to choose their religion and it is against human values to covert somebody forcibly. For him, humanity comes first whereas religion is a personal affair. In his view, it is the right of the individual who has the right to decide his religion. Akhtar and Kartar stand for the two communities, the Muslims and the Sikhs, which were suffering the forcible conversion. Every conversion was considered a service to the religion. Akhtar's helplessness reminds him of Kartar's misery across the border that he may also be converted. This thought makes him feel the agony of the people who were being converted forcibly. His compassion for the victims of conversion invokes in him a revolt against religious fanaticism.

Amar Kaur, the daughter of Parmeshar, cannot accept Akhtar as Kartar, for he is a Muslim. She thinks Kartar not to be a Muslim. "And Kartara just can't ever be a Muslla ${ }^{11 . "}$ (Qasmi, 2010). Her hatred for Akhtar is based on the meta-narrative that the Muslims are impure, untrustworthy and inferior to Sikhs. Therefore, Akhtar can never replace Kartar for her. Her hatred for Muslims is due to the meta-knowledge of the Muslims, which was never investigated. This meta-narrative sustains because she keeps herself away from Akhtar. When Akhtar and Parmeshar come closer, this meta-narrative is rejected. Parmeshar Singh portrays how a Sikh villager rises above the narrow communal and societal contemplations on helping and rescuing people irrespective of their religion. This act of humanity among his people wrought by the dominant meta-narrative around them establishes Parmeshar Singh someone like a saviour removed far from the pettiness of his fellow; earthly human beings.

One night, the whole Sikh family is terrified except Parmeshar by a voice reciting the Holy Quran. Amar Kaur's shriek terrifies Akhtar. Parmeshar approaches him and tells that they heard the recitation of the Holy Quran. "That was me", Akhtar said. "I was reciting it" (Qasmi, 2010). Parmeshar asks him to recite it for him. And when Akhtar finishes, he asks him if he should breathe on him? "yes, yes" Parmeshar quickly flung upon his collar."..."you should recite it every day. Loudly. Never forget it" (Qasmi, 2010). Parmeshar is not horrified as he is familiar with this Quranic recitation because of his visions of recitation. Such visions cannot be had if he sticks to religious prejudice. When he comes to know that it was Akhtar who was reciting Quran, he is rather relieved. His strong love for Akhtar makes him shed all his religious fears. Earlier, he has saved Akhtar from conversion, now he allows him to practice his religion, Islam, in a Sikh house. He permits him to practice his religion merely on humanitarian grounds because it is the right of individual to have the freedom to practice his religion. As a human being he does not want to erode his religious identity, rather he wishes to maintain it. He advises Akhtar to recite the Quran daily. He even asks Akhtar to breathe on him just to please Akhtar as Parmeshar does not like to hurt him.

One day, Parmeshar notices that a neighbouring child is crying with pain for there was a thorn darted into his foot. The mother of the child rushes to him. She is so moved by her child's cries that she even forgets to cover her head. She removes the thorn and kisses him madly. Parmeshar asks his wife if she still misses Kartar? (Qasmi, 2010). She replies mournfully, "Parmeshare! Kartara is the wound in my heart which will never heal." The same evening, he decides to send Akhtar across the border. He cannot afford to lose Akhtar but he is not selfish in his affection. When his neighbour woman runs to her crying son, he is moved by the event and he thinks of his wife whose son is missing.

\footnotetext{
${ }^{11}$ A derogatory slang for the Muslims 
He is shaken within when his wife bursts into tears. It proves to be his moment of realization and he identifies his wife with Akhtar's mother who would also be waiting for her son impatiently. His own wish is to keep Akhtar with him but Akhtar's chief bliss is to see his mother. He sacrifices his desire for the happiness of Akhtar and his mother. He prefers love of humanity to his love for a son. He feels the pain of all those unfortunate people who were separated from their loved ones-- husbands, wives, fathers, mothers, sons, daughters, etc. Parmeshar thinks it his foremost duty to reconcile a lost son with his desperate mother who would be waiting for her son anxiously. In spite of his deep love for Akhtar, he could solace neither Akhtar's sense of deprivation, nor of his own wife and daughter's. Resultantly, he himself could not achieve the sense of satisfaction which he wanted to achieve through Akhtar. Now he wants to achieve that sense of satisfaction by reconciling Akhtar with his mother.

At night, he puts Akhtar on his shoulders to take him to the border. On the way, he narrates a tale to amuse Akhtar. He narrates the tale of Guru Gobind Singh ${ }^{12}$ but changes the names of the characters from Sikh to Muslim. Though Parmeshar has deep faith in his religion, and he is very proud of his heroes yet he puts aside his religion and culture for a Muslim child who is going to depart forever. Akhtar was the only substitute for Kartar, his son. He changes the names of the Sikh characters because he cannot afford to hurt Akhtar. Akhtar is a Muslim and is emotionally attached to his own religion and does not tolerate any other religion. Parmeshar's selfless love for Akhtar presses him to rename the characters only to please Akhtar. This act of sending Akhtar across the border signifies the humane elements on both the sides who were working selflessly for humanity. Parmeshar's attempt of getting Akhtar accepted by his family and folks goes futile and it does not affect Akhtar's sentiments too. Eventually, Parmeshar Singh ends up realizing the ineffectiveness of his attempt, therefore, he accompanies the boy to the Pakistani border to restore Akhtar to his desperately waiting mother. Parmeshar's resolution of restoring Akhtar to his mother is not because he thinks Akhtar "naturally belong" there, but it is instigated by his own people to feel Akhtar alien, misfit amongst strangers and religiously other.

On reaching the border, Parmeshar directs Akhtar towards the village across the border. Akhtar crosses the border and is stopped by the soldiers who suspect him to be a Sikh. They suspect him due to his Kes and turban whereas he claims his name is Akhtar. Meanwhile, they notice a Sikh man rushing towards the border and they shot him when he crosses the border. The soldiers go near the bleeding man who turns out to be Parmeshar Singh. He says in delirium, "why did you have to shoot me? I just forgot to clip Akhtar's kes! I only come to return Akhtar his Dharam ${ }^{13}$ (Qasmi, 2010). Parmeshar forgets to clip Akhtar's hair in the haste of reuniting Akhtar with his mother as soon as possible as he does not want to prolong Akhtar's grief. He crosses the border to cut his hair as he does not want to corrupt Akhtar's identity. He rescued a Muslim boy, raised him as a Muslim and now wants him to be returned as a Muslim. He knows that the society across the border will not accept Akhtar in a Sikh attire. The soldiers vividly manifest the attitude of the society that a man with kes and turban must be a Sikh. It is because India was divided on basis of religion. Both the societies have become intolerant to each other. The firing strengthens the meta-narrative of the bloodbath and inhumanity. There is a rejection of the meta-narrative in Parmeshar's sacrifice that many people instead of killing others, sacrificed their own lives for the safety of others, irrespective of their religion.

\section{Conclusion}

Jean-Francois Lyotard significantly inspects the status of knowledge in the postmodern conditions. Unlike postmodernism, modernism solidifies the unified theories and models in the form of binary oppositions, Lyotard violates such unification of theories and singularity of meanings. This legalizes the narration of meta-narratives by marginalizing the impacts of the opposite, unreasoning are subverted by rationality.

Though these stories advocate violence and hatred, yet there is ample evidence in the partition literature which manifests acts of love, kindness and humanity. These stories show

\footnotetext{
$1210^{\text {th }}$ Sikh spiritual master called Guru.

${ }^{13} \mathrm{~A}$ word for religion in Punjabi.
} 
other aspects of partition which have not been explored yet. In spite of the fact, there are many works which manifest such events other than bloodshed, a reader never pays heed to them or they are left unnoticed. There are such balanced accounts in perspective of partition which depict the humane side of the event. These stories manifest those unsung tales which glorify the humanity and compassion. This portion of the partition literature describes the tenderness merely on the basis of human sympathy at the time of havoc. The long-existed harmony of the people of the subcontinent did not turn to frenzy or to hatred overnight, they helped each other endangering themselves and made sure the safety of the people who were going to migrate. These tales manifest a great amount of benevolence and humanity which give another outlook to the popular narrative of the partition that is tender and humane.

These politically enthused meta-narratives are inspected by deploying postmodernist principles provided by Jean-Francois Lyotard. Under the influence of Lyotard's theory of metanarratives, the text is examined, which questions the singularity of the knowledge asserting the self-reflexivity of the text by exploring multiple interpretations of the history. It advocates the plurality of the meaning in the postmodern conditions by decentralizing and identifying the humane aspects of the partition narrative and constructing an alternative narrative. Hence, this research by synchronizing the new perceptions of the meta-narrative, arrives at the conclusion by establishing an alternative narrative of the partition narrative.

\section{References}

Baudrillard, J. (1995). Simulacra and Simulation (1st ed.). USA: Ann Arbor, University of Michigan press.

Best, S. (1991). Postmodern Theory: Critical Interrogations. New York: Guilford Publications.

Bishop, T. G. (1996). Shakespeare and the Theatre of Wonder. London: Cambridge University Press.

Boyne, R., \& Rattansi, A. (1990). Postmodernism and Society. London: Bloomsbury Publishing.

Butler, C. (2003). Structure and Function: Approaches to the simplex clause. Netherland: John Benjamins Publishing.

Derrida, J. (1997). Of Grammatology (Corrected ed. ed.). Baltimore and London: Johns Hopkins University Press.

Foucault, M. (1970). The Order of Things: An Archaeology of the Human Sciences. New York: Vintage.

Foucault, M. (1982). The Subject and Power. Critical inquiry, 8(4), 777-795. doi:https://doi.org/10.1086/448181

Jameson, F. (1991). Postmodernism, or, The Cultural Logic of Late Capitalism. Durham, North Carolina: Duke University Press.

Kuznar, L. A. (2008). Reclaiming a Scientific Anthropology. Lanham, MD: Rowman Altamira.

Lyotard, J.-F. (1984). The Postmodern Condition: A Report on Knowledge. USA: University of Minnesota Press.

Lyotard, J. (1992). The Postmodern Explained. In. Minneapolis: University of Minnesota Press.

Major, A. (1998). The Chief Sufferers: Abduction of Women during the Partition of Punjab. Washington DC: Sage Publishers.

Nietzsche, F. (1954). On Truth and Lie in an Extra-Moral Sense. New York: Penguin.

Qamsi, A. N. (1958). Parmeshar Singh. Lahore, Pakistan: Snage-Meel Publishers.

Qasmi, A. N. (2010). The Resthouse. New Dehli, India: KATHA Press.

Spiro, M. E. (1996). Postmodernist Anthropology, Subjectivity, and Science. A Modernist Critique. Comparative studies in society and history, 38(4), 759-780. doi:https://doi.org/10.1017/S0010417500020521 